\title{
TAALBESKOUING EN TAALSTREWE VAN DIE
}

\author{
G. R. A.
}

(Die Redaksie plaas hierdie artikel juis in die Augustusuitgawe van Koers: die Genootskap van Regte Afrikaners is op 14 Augistus 1875 gestig. Hoewel die beweging wat hieruit ontstaan het, uiteindelik' $n$ veel w'yer onvang aangeneem het en die bewuste kanalisering van ,die Afrikaanse gedagte" geword het, was hulle uitgangspunt en einddoel die taal, met name die taal van die Bybel. In die artikel word enkele gesigspunte met betrekking tot hulle taalbeskouing en hulle strewe in verband met die taal behandel.)

Die taalbeskouing van die Genootskappers is deur verskillende voorstanders van Afrikaans geformuleer, o.a. deur Pannevis (in sy „Gesprek”, wat deur J. D. du Toit in S. J. du Toit in weg en werk, bl. 102-107, aangehaal word), deur C. P. Hoogenhout (in sy Gesprekke tusse Jan Vasvat en neef Daantje Loslaat), deur Oom Lokomotief (in Die Patriot, waarin hy met sy kensketsende joernalistieke vaardigheid en gevatheid die aanvalle op Afrikaans oortuigend weerlê het). Maar dis die duidelikste geformuleer deur S. J. du Toit, aanvanklik en voorlopig in Die eerste beginsels van die Afrikaanse taal maar die omvattendste en wetenskaplikste in Afrikaans ons volkstaal; 71 theses of stellinge. Verder het die manne van die Eerste Beweging veel te danke aan dr. Brill, wat self geen voorstander van Afrikaans was nie maar wat in 1875 in Bloemfontein die goeie reg en die wetmatigheid

van die ontwikkeling van Afrikaans betoog het. Bowendien lewer die Theses bewys dat S. J. du Toit talryke gesaghebbende taalkundiges van sy 
tyd geraadpleeg het voor hy tot die finale formulering van sy beskouing gekom het.

Die taalbeskouing van die Genootskappers word eensdeels en veral aanıanklik in 'n groot mate beïnvloed deur hulle taalstrewe. Toe Pannevis in 1872 in De Zuid-Afrikaan die Bybelvertaling bepleit het en toe hy in 1874 sy brief aan die Britse en Buitelandse Bybelgenootskap geskryf het, was dit hom nie in die eerste plek om die taal as sodanig te doen nie maar om die taal as middel tot evangelisasie en sending: die gekleurde bevolking veral het, volgens hom, die Nederlandse Bybel nie begryp nie. Hy was dus hier nie in eerste instansie besig met 'n pleidooi vir die taal nie, hoewel hy ook die Bybel die doel wou laat dien om die volk aan die taal te wen. Daarom gebruik hy ook die ongelukkige woorde dat Afrikaans 'n soort verbasterde Hollands is. As hy egter later, in 1875, in sy ,Gesprek over het Kaaps-Hollands" die volwaardigheid van Afrikaans as taal wil bewys, is die toon heeltemal anders, en daar word ook nie van Afrikaans gewag gemaak as ,,a kind of corrupted Dutch", 'n soort brabbeltaal wat met verloop van tyd ontstaan het gedeeltelik as gevolg van verwaarlosing van die nocdertaal nie. Dit stem nou reeds meer ooreen met die vroeëre uitlatings van die ,Regte Afrikaners". By Hoogenhout, byvoorbeeld, is die pleidooi besiel met 'n eg-Afrikaanse gees. Al meer en meer sal ons opmerk dat dic beskouinge oor die taal 'n propagandistiese en selfs chauvinistiese kleur kry.

Hoogenhout sâ byvoorbeeld in sy Gesprekke: „Afrikaans is een gawe taal, net maar daar is banja wat te parmantig is om dit te erken.....". Dieselfde chauvinistiese en propagandistiese tendens vind ons in S. J. du Toit se Eerste beginsels, in die eerste plek in die „,gedig” „Die Afrikaanse taal" wat daaraan voorafgaan: dit is eng chauvinisties en gee in geen opsig in getalanseerde taalbeskouing nie:

Gen Hollans, Duits, of Frans,

Gen Engels, of Javaans,

Gen Kaffers, of Boesmans, Al goi jy almal in die skaal, Ver ons kan hulle nooit ophaal Die ware Afrikaanse taal.

Die propagandistiese vind ons ook in ,'n Woortji voorar", bv. in: ,Ons het hierin getoon, dat Afrikaans net so goed 'n taal is as enige taal van di wêreld. Hy het not so goed syn woorde, syn vorme, syn wette, ens. En ons daag enige vyand uit te bewys, dat dit ni so is ni". En selfs waar hy die grammatika van die taal behandel, hoor ons dit: „By di twede per- 
soon is ons taal duideliker as Hollans en Engels albei, omdat ons twe aparte woorde gebruik ver enkelvoud en meervoud en hulle ni". Hierdie houding skemer selfs in sy Theses nog deur, as hy in die 10de stelling beweer: „Wat suiwerheid angaan is di Afrikaanse taal vandag di suiwerste tak van di oue Germaanse of Dietse taalstam, waaruit soveule nuwe tale gespruit het". In verband met die stellinge moet mens net onthou dat hulle uiteraard polemies van aard is, want hulle word juis opgestel om die waardigheid en goeie reg van Afrikaans teenoor Nederlands te stel.

Sulke en dergelike uitlatings moet gesien word in die lig van die uitgangspunt en einddoel van die Genootskappers: hulle wil die Bybel in Afrikaans vertaal hê en wil die volk gevolglik oortuig dat hulle spreektaal ook hulle skryf- en leestaal kan en moet wees. Daarom wil hulle die volk eerstens oortuig van die waardigheid van hulle taal en daarna leer om hulle taal lief te kry en te anvaar. Vandaar dan die klinkende lofuitings: die volk moet geleer word om hulle nie te skaam vir hulle taal, wat deur die teenstanders belaster en beswadder word nie.

Later word die strewe veel omvattender. In sy Theses eis $\mathrm{Du}$ Toit nie alleen die reg vir Afrikaans op om Bybeltaal te wees nie, maar hy spreek van Afrikaans ons Moedertaal, ons Landstaal, ons Volkstaal, ons Skryftaal, ons Bybeltaal, ons Skooltaal, ons Kerktaal. Met ander woorde hulle strewe nou om Afrikaans erken te kry as amptelike taal op al die verskillende lewensterreine. Dán merk ons dat die beskouinge waardiger, wetenskapliker en beter verantwoord ingeklee word. En dat dit nie S. J. du Toit se beskouinge alleen was nie, blyk uit die feit dat hierdie stellinge deur Oom Lokomotief, ongetwyfeld met instemming, namens die opsteller voorgedra is op die taalkongres waarvoor hulle geskryf is.

In hulle beskouinge oor die wese van taal bly hulle deurgaans min of meer suiwer. Reeds in die Eerste beginsels sê S. J. du Toit: „Ons weet te goed dat gen taal, nes 'n swareweersteen, somar kant en klaar uit di hemel val ni. Dit neem lank tyd om 'n taal goed te kry. Kyk mar Hollans en Engels: wat was dit eers, en wat is dit nou? En heeltemal volmaak word gen taal ooit ni. Want waar is 'n taal wat ni syn foute en gebreke en onregelmatighede het ni". (In die laaste deel hoor ons weer die propagandistiese.) In sy Theses, nr. 1, sou hy dit veel kernagtiger en wetenskapliker formuleer: ,'n Taal is 'n organise, ni 'n meganise ding nie; iits wat gebore, mar ni gemaak word ni; its wat altyd groei, en nooit kant-en-klaar is ni". Hy betoog verder dat die Afrikaanse taal die natuurlike wette van vereenvoudiging gevolg het (st. 8), en in stellinge 10-16 beklemtoon hy die suiwer- 
heid, kortheid, bondigheid, rykdom, sagtheid, welluidendheid, eenvoudigheid, reëlmatigheid en eenvormigheid van die taal.

Opmerklik is die klem wat voortdurend en deurgaans op die spreektaal gelê word. In die vyfde stelling sê S. J. du Toti : „Di Taal self is di hoogste wetgewer. Dus kan jy gen taalreels an 'n Taal voorskrywe ni, jy moet dit an di Taal ontleen. Di Skryftaal moet di Spreektaal volg, ni omgekeer ni”'. Daar word ook voortdurend verwys na die spreektaal as die voedingsbodem van die skryftaal. Die skryftaal moet hom geheel en al na die spreektaal rig, steeds vernuut na aanleiding van die spreektaal. Uit hierdie standpunt moet hulle in 1874 neergelegde en in 1890 nog gehandhaafde stelreël besien word: „Ons skryf soos ons praat".

Met hierdie reěl openbaar hulle fyn insig, en dit staan ten volle in diens van hulle taalstrewe: hulle wil die volk gewoond maak om sy spreektaal ook te skryf; en as hulle met ingewikkelde taal- en spelreëls sou kom, sou hulle die volk verwar en vervreemd. Dat hulle hulle daarby terdeë rekenskap gegee het van die taal in sy lewende, gesproke vorm, blyk van tyd tot tyd uit uitsprake. So verklaar S. J. du Toit in die voorwoord tot die tweede druk van die Eerste beginsels: „Sulle ver Hulle het ons lat vaar: dis ni in ons taal tuis genoeg ni. Weinige gebruik dit".

Ook S. J. du Toit se fonetiese spellingstelsel is in hierdie beginsel gefundeer. Hy werp eenvoudig die historiese spellingbeginsels en skryftradisie oorboord: die spreektaal is die hoogste wetgewer en moet so noukeurig en konsekwent moontlik weergegee word. Dit het rampspoedige gevolge gehad vir die Beweging: die volk kon die vreemde, geheel en al van die bekende Nederlandse spelwyse afwykende taal nie aanvaar nie. Dis dan ook een van die belangrike redes hoekom die Bybelvertaling tydens die Eerste Beweging misluk het.

Hoe prakties en sielkundig die reël ,skryf soos jy praat" origens ook gewees het, daar is twee aspekte waarmee die Genootskappers nie rekening gehou het nie: 1. Hulle het hulle nie rekenskap gegee van die belangrike funksie van die skryftaal met betrekking tot die spreektaal nie, nl. dat dit kultiverend, remmend en behoudend is. 2. Hoewel die G.R.A. met praktiese sin leiding gegee het, het hulle nie voldoende pogings in die werk gestel om die gevare wat in hulle grondreël skuil, te temper nie. Die logiese gevolg van die deurvoering van die rełl was dat daar geen konsekwente skryfwyse in Afrikaans was nie. En dit was 'n baie handige stok wat die bevegters van die taal gretiglik aangegryp het om teen die taal op te hef en die mensa daarteen bevooroordeeld te maak. 
Ook teenoor die ander twee tale het die Genootskappers hulle houding bepaal. Teenoor Engels neem hulle, begryplikerwys, vierkantig stelling in; begryplikerwys, want Engels het die ideaal van 'n eie Afrikaanse spreeken skryftaal ondubbelsinnig bedreig. Nogtans erken hulle dat Engels die een taal in Suid-Afrika sal bly, en met praktiese insig merk S. J. du Toit ook op dat Engels ' $n$ veel makliker taal as Hollands is om te leer, omdat dit 'n eenvoudiger taal is.

Teenoor Hollands is hulle nie vyandig gesind nie, want hulle besef dat hulle die steun van Hollands nodig het in hulle stryd teen verengelsing. S. J. du Toit verwyt dan ook die voorstanders van Hollands hulle vyandigheid teen Afrikaans, want Afrikaans het Hollands onmiskenbare dienste bewys, wat hy ook met voorbeelde staaf in die toeligting van die stellinge. Reeds in die sewentiger jare het Oom Lokomotief in Die Patriot die standpunt van die alte vurige voorstanders van Afrikaans dat Hollands nou maar oorboord gegooi kan word, teëgegaan. As A. J. Herholdt in sy „Afrikaanse liidji" daarop aandring dat Hollands met die skuit weggestuur moet word, sê Oom Lokomotief: „Ons stem nie met hom same dat die Hollans met die skuit moet weggestuur worde na Holland nie. Ons het Hollans vereers nog nodig". Ook in sy voorwoord tot sy stellinge meen S. J. du Toit dat die gematigde voorstanders van Holllands-die wat 'n vereenvoudigde Hollands voorstaan-saam met die voorstanders van Afrikaans 'n taalkongres moet hou om tot ' $n$ vergelyk te kom. En in die 44ste stelling klink die vriendskaplike houding baie duidelik: „Afrikaans het sig dan oek nooit vyandig getoon teen Hollans ni, mar alle pogings tot behoud van Hollans teeno'er Engels ondersteun, in die o'ertuiging dat Hollans hiir tog die erfdeel is van Afrikaans".

Dit is dan die karakteristieke van hulle houding teenoor Hollands dat hoewel hulle so vriendskaplik en simpatiek en welwillend daarteenoor staan, hulle nogtans beslis is dat Afrikaans die plek van Hollands sal moét inneem. Dit is vir hulle nie alleen natuurlik en billik nie maar ook nodig en noodwendig; nodig, omdat die behoud van die spreektaal die enigste moontlikheid is om verengelsing te stuit; noodwendig en vanselfsprekend, omdat dit die ,weg van vooruitgang" is en omdat Nederlands nie die vitaliteit het om te bly voortbestaan nie en bowendien te moeilik is om te leer. Hulle wil Hollands voorlopig bewaar, ,wetende dat di toekoms ons toebehoor". „Hollans beskou ons as ' $n$ stut om di jonge Afrikaanse taalplant te ondersteun. Mar by di dag word di jonge boompi sterker en di paal vrot weg. En as di paal di dag omval, dan kan di boompi oek al alleen staan." (Vgl. 
verder stt. 36, 37, 41, 42, 43, 44, 63.) Hulle wys ook daarop dat Hollands selfs nie eens meer deur die predikante suiwer gebesig word nie.

Ons merk dus dat hierdie voorstanders van Afrikaans hulle terdeë rekenskap gegee het van wat hulle strewe is en daarvolgens met doelbewustheid die taal beoefen het, rigting aangedui het en hulle standpunt onomwonde, soms selfs reaksionêr, geformuleer het. Die treffendste is seker dat hulle hulle standpunt geformuleer en gehandhaaf het met 'n stralende idealisme en in die kalme wete dat hulle werk met die oog op die toekoms, wat aan hulle behoort. Só stel Du Toit dit in sy 47ste stelling: „Di verwagting van 'n eie nasionaliteit, 'n eie beskawing, 'n eie letterkunde, hiir in Suid Afrika (gekoester deur ons edelste en geleerdste manne) is dus glad ni 'n ydele droombeeld ni, mar 'n heerlike ideaal ver Jong Suid Afrika!-(Dr. Brill.)"

P.U. vir C.H.O.,

HERTZOG VENTER.

Augustus 1956. 